\title{
Detrimental Effects of Blood Meal and Feather Meal on Tomato (Solanum lycopersicon L.) Seed Germination
}

\author{
Juan Carlos Diaz-Perez ${ }^{1}$ and W. Keith Jenkins \\ Department of Horticulture, University of Georgia, 2360 Rainwater Road, \\ Tifton Campus, Tifton, GA 31793-0748
}

Dharmalingam Pitchay
Tennessee State University, 3500 John A Merritt Blvd, Nashville, TN 37209

Gunawati Gunawan

University of Georgia, 2360 Rainwater Road, Tifton Campus, Tifton, GA 31793-0748

Additional index words. organic, fertilizer, ammonia, nitrification, nutrition

\begin{abstract}
There is limited information on the effect of organic fertilizers on seed germination and subsequent transplant growth. The objective of this study was to determine the effects of application rate of blood meal (BM) and feather meal (FM) fertilizers on germination of tomato seeds. Both organic fertilizers were applied as amendments to peat-based organic substrates at rates ranging from 0 to over $50 \mathrm{~g} \cdot \mathrm{kg}^{-1} \mathrm{~N}$. Tomato 'Brandywine' seed were sown in trays. Seed germination was recorded daily until the germination percentage remained unchanged. Ammonia concentration in the substrates (Pro-Mix and Miracle-Gro) increased with increasing rate of substrate $\mathbf{N}$ concentration. Ammonia concentration also increased with increasing time after incorporation of $B M$ and $F M$ reaching maximum values $(16 \mathrm{ppm})$ at day 9 . Tomato seed germination was little affected at $B M$ and $F M$ rates lower than $\approx 3 \mathrm{~g} \cdot \mathrm{kg}^{-1} \mathrm{~N}(4 \% \mathrm{w} / \mathrm{w}$ for BM or FM), but declined above $3 \mathrm{~g} \cdot \mathrm{kg}^{-1} \mathrm{~N}$ reaching $0 \%$ germination rate at $\approx 14 \mathrm{~g} \cdot \mathrm{kg}^{-1}$ $\mathrm{N}$ for both BM and FM. Substrates pH was 5.9 in the absence of BM or FM and increased to about $\mathrm{pH} 7$ with addition of low rates of $\mathrm{BM}\left(2.7 \mathrm{~g} \cdot \mathrm{kg}^{-1} \mathrm{~N}\right)$ and $\mathrm{FM}\left(2.6 \mathrm{~g} \cdot \mathrm{kg}^{-1} \mathrm{~N}\right)$. Substrate electrical conductivity (EC) increased with increasing substrate $\mathbf{N}$ concentration as supplied by BM and FM; FM, however, had a stronger effect on increasing EC compared with BM. In conclusion, BM and FM had inhibitory effects on tomato seed germination when applied at more than $3 \mathrm{~g} \cdot \mathrm{kg}^{-1} \mathrm{~N}(4 \% \mathrm{w} / \mathrm{w}$ for BM or FM). High ammonia concentration in the substrates for the first 2 weeks after incorporation of BM or FM likely caused, at least partially, inhibition of tomato seed germination. Thus, substrate mixed with BM or FM should be allowed to incubate for at least 2 weeks before planting tomato seed.
\end{abstract}

For premium quality transplant production, it is critical to provide balanced and complete nutrition before and after seed germination. In organic production systems, nutrient management is complex and variable, unlike in inorganic production systems that allow for precise and readily nutrient availability (Russo, 2005). Organic transplant production typically involves incorporating an organic fertilizer or amendment into the substrate. The effects of the organic

Received for publication 18 July 2016. Accepted for publication 1 Nov. 2016.

We appreciate the thorough review of the manuscript by Tim Coolong, Erick Smith, and the anonymous reviewers. We thank Glenn Burress, Premier Tech, for donation of Organic Pro-Mix substrate and Georgia Agricultural Experiment Stations for the financial support.

Mention of trade names in this publication does not imply endorsement by the University of Georgia of products named, nor criticism of similar ones not mentioned.

${ }^{1}$ Corresponding author. E-mail: jcdiaz@uga.edu. fertilizers on vegetable seed germination and subsequent transplant growth are not well understood (Díaz-Pérez et al., 2008; Dufault, 1998; Hartz and Johnstone, 2006; Nair et al., 2011).

There are few studies on the use of BM and FM fertilizers for both transplant and field productions (Hadas and Kautsky, 1994; Jenkins, 2009). Tomato transplants and other vegetables have been successfully produced in peat-based substrate mixed with BM and $\mathrm{FM}$ at $2.2 \mathrm{~g} \cdot \mathrm{kg}^{-1} \mathrm{~N}$ (Gagnon and Berrouard, 1994) and with $\mathrm{FM}$ at $2.7 \mathrm{~g} \cdot \mathrm{kg}^{-1} \mathrm{~N}$ (Koller et al., 2004). Blood meal ( $12 \%$ to $14 \% \mathrm{~N})$ and FM $(7 \%$ to $13 \% \mathrm{~N})$ have higher levels of $\mathrm{N}$ than other organic fertilizers (Hartz and Johnstone, 2006). This high $\mathrm{N}$ concentration makes the use of BM and FM an attractive option for organic transplant production as less fertilizer material is needed compared with other organic fertilizers.

Nitrogen mineralization is the process by which soil microorganisms transform organic $\mathrm{N}$ in organic fertilizers into $\mathrm{NH}_{4}^{+}-\mathrm{N}$. Nitrogen mineralization increases with temperature
(Agehara and Warncke, 2005; Zak et al., 1999). Commonly, $\mathrm{pH}>7.5$, high temperature, accumulation of phenolic-based allelopathic compounds, and poor oxygen supply (e.g., poor substrate draining due to container tray geometry) inhibit nitrifying microorganisms, resulting in higher rates of net ammonification than net nitrification (Britto and Kronzucker, 2002). Seed germination and seedling establishment can be inhibited by ammonia (Cook, 1962). Symptoms of ammonia toxicity appear when external ammonia concentration is above 0.1 to $0.5 \mathrm{mmol}$ ( 1.7 to $8.5 \mathrm{ppm}$ ) (Britto and Kronzucker, 2002).

Nitrogen mineralization in BM and FM is fast (Hartz and Johnstone, 2006; Mondini et al., 2008), with the highest ammonia production occurring in the first (Agehara and Warncke, 2005; Hartz and Johnstone, 2006) and second weeks (Koller et al., 2004). Khalil et al. (2005) observed a rapid increase in ammonia production in the first 2 weeks for crop residues and chicken manure. The potential of BM as an effective organic fertilizer was supported by the large increase in available $\mathrm{N}$ and the enhancement of the size and activity of soil microorganisms. Blood meal and FM, however, may be detrimental to seed germination and transplant growth. Rosemary transplants had reduced root development when grown with FM (Pitchay and Díaz-Pérez, 2008; Valenzuela et al., 2001). The objective of this study was to determine the effects of application rates of BM and FM on tomato seed germination.

\section{Materials and Methods}

The study was carried out at the Department of Horticulture, University of Georgia, Tifton, GA. Germination tests were conducted in both growth chamber and greenhouse conditions to eliminate possible artifacts associated with the site where germination was conducted.

Test 1. Certified organic tomato (Lycopersicum esculentum) seed 'Brandywine' (Johnny's Selected Seeds, Winslow, ME) were planted $(2 \mathrm{seed} /$ cell $)$ in Styrofoam trays with 200 cells (Speedling Inc., Sun City, FL) filled with peat-based organic potting substrate (Fafard's FOF 20; Conrad Fafard, Inc., Agawam, MA) composed of $70 \%$ Canadian sphagnum peat, perlite, dolomitic limestone, and gypsum. After seeding, trays were kept in a greenhouse (mean temperature $=23^{\circ} \mathrm{C}$ ). The duration of each germination test was $21 \mathrm{~d}$. This test was conducted three times.

Test 2. Plant material was as in Test 1. Potting substrate was an organic mix (ProMix, Rivière-du-Loup, QC, Canada). After seeding, trays were kept in a growth chamber (CMT-3244, Convirons, Hendersonville, $\mathrm{NC} ; 22{ }^{\circ} \mathrm{C} ; 80 \%$ to $90 \%$ relative humidity; 12-h day/12-h night photosynthetically active radiation). This test was conducted twice.

Test 3. Plant material was as in Test 1 . Potting substrate was an organic mix (Miracle-Gro, Marysville, OH). After seeding, trays were kept in a growth chamber as in Test 2. This test was conducted once. 

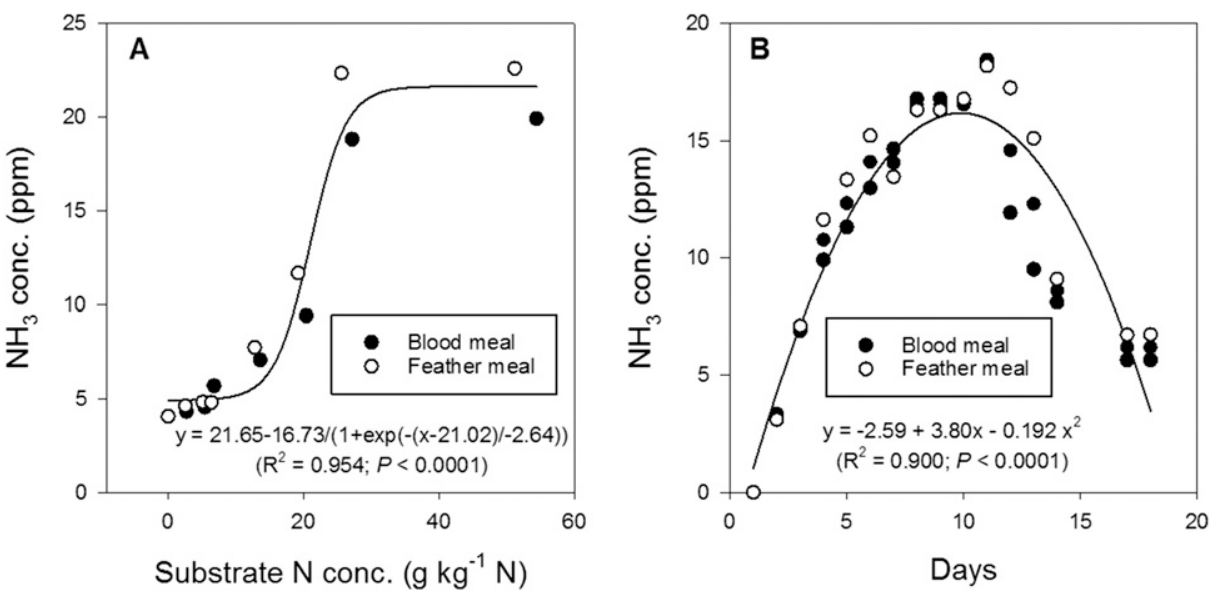

Fig. 1. Effect of nitrogen concentration in the substrate (A) and time after incorporation of organic fertilizer (B) on ammonia concentration in the substrate. Nitrogen was applied as blood meal $(13.6 \% \mathrm{~N})$ or feather meal $(12.8 \% \mathrm{~N})$ fertilizer. Values represent means across substrates $($ Organic Pro-Mix and Organic Miracle-Gro). Solid line in panel A was fit with nonlinear regression using a sigmoidal fit. Solid line in panel B was calculated using linear regression.

Experimental design for the three tests was a randomized complete block with 4 replications and 16 treatments $[2$ fertilizers $(\mathrm{BM}$ and $\mathrm{FM}) \times 8$ rates]. Blood meal $(13.6 \mathrm{~N}-0 \mathrm{P}-0 \mathrm{~K})$ and FM $(12.8 \mathrm{~N}-0 \mathrm{P}-0 \mathrm{~K})$ (both from Boer Commodities, Fresno, CA) were mixed at different rates with the potting substrate immediately before seeding. Rates of BM were $0,2.7,5.4,6.8,13.6,20.4,27.2$, and 54.4 $\mathrm{g} \cdot \mathrm{kg}^{-1} \mathrm{~N}$, which were equivalent to $0 \%, 2 \%$, $4 \%, 5 \%, 10 \%, 15 \%, 20 \%$, and $40 \% \mathrm{BM}(\mathrm{w} / \mathrm{w})$ in the substrate [wet at full moisture-holding capacity $(\approx 40 \%, \mathrm{v} / \mathrm{v})]$, respectively. Rates of FM were 0, 2.6, 5.1, 6.4, 12.8, 19.2, 25.6, and $51.2 \mathrm{~g} \cdot \mathrm{kg}^{-1} \mathrm{~N}$, which were equivalent to $0 \%$, $2 \%, 4 \%, 5 \%, 10 \%, 15 \%, 20 \%$, and $40 \% \mathrm{FM}$ $(\mathrm{w} / \mathrm{w})$ in the substrate [wet at pot capacity $(\approx 40 \%, \mathrm{v} / \mathrm{v})]$, respectively. Water content of $\mathrm{BM}$ and $\mathrm{FM}$ was negligible. The experimental unit consisted of 12 tray cells $(4 \times 3$ cells section in a tray; 2 seeds per cell), and a block consisted of a single tray. There was a line of empty tray cells between experimental units.

Germination percentage for the three tests was assessed daily until there was no change in seed germination. Ammonia from amended substrates was measured (only in Tests 2 and 3) daily with Hydrion Ammonia Test Paper (2006003; QA Supplies, Norfolk, VA), using a $1 \mathrm{~cm}$ length of test paper, moistened in distilled water, and placed directly on the substrate surface for $1 \mathrm{~min}$ ( $\mathrm{Ni}$ and Heber, 2008). The amended substrates were mixed with water $(1: 2 \mathrm{v} / \mathrm{v})$ and incubated overnight, and $\mathrm{pH}$ and $\mathrm{EC}$ of the substrate solution were measured (four replications per treatment) with a pH/EC meter (model HI9813-6; Hanna Instruments United States, Inc., Woonsocket, $\mathrm{RI})$. Ammonia concentration, $\mathrm{pH}$, and $\mathrm{EC}$ were not measured for the Fafard substrate (Test 1).

Data were analyzed by pooling data from the three tests (for seed germination) or from Tests 2 and 3 (for ammonia concentration, $\mathrm{pH}$, and EC) using the General Linear Model and Regression Procedures of SAS software (version 9.1; SAS Institute Inc., Cary, NC) and the least significant

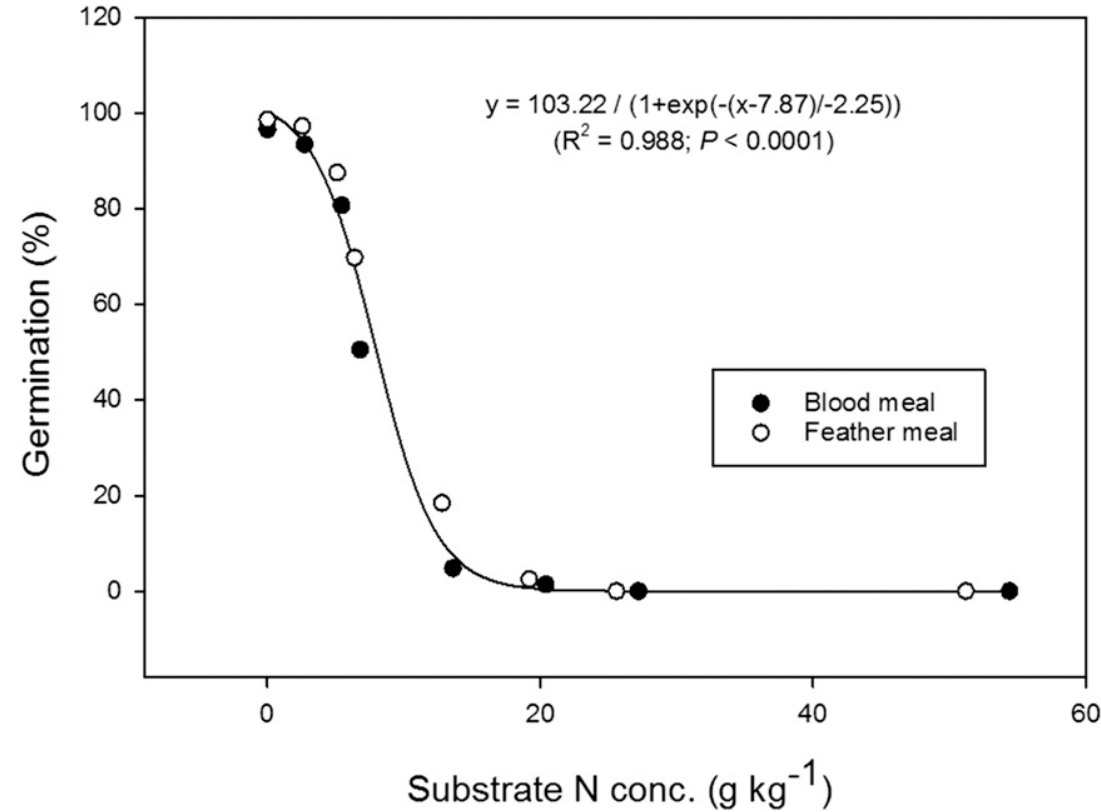

Fig. 2. Effect of nitrogen concentration in the substrate on tomato seed germination. Nitrogen was applied as blood meal $(13.6 \% \mathrm{~N})$ or feather meal $(12.8 \% \mathrm{~N})$ organic fertilizer. Values represent means across substrates (Fafard FOF 20, Organic Pro-Mix, and Organic Miracle-Gro). Solid line was fit with nonlinear regression using a sigmoidal fit.

difference test $(P \leq 0.05)$ to separate the treatment means. Several regression models were evaluated with SAS and SigmaPlot (version 13; Systat Software Inc., San José, CA) to fit the data using both linear and nonlinear regression models. There were no interactions between experiments and the response variables, thus data for the tests were pooled.

\section{Results}

Ammonia. Ammonia concentration in the substrates (Pro-Mix and Miracle-Gro) increased with increasing rate of substrate $\mathrm{N}$ concentration (Fig. 1A). Ammonia concentration was low $(<5 \mathrm{ppm})$ with $\mathrm{N}$ rates less than $6.4 \mathrm{~g} \cdot \mathrm{kg}^{-1} \mathrm{~N}$. Across substrates, mean ammonia concentration in $\mathrm{BM}(9.2 \mathrm{ppm})$ was similar to that of FM (10.4 ppm). Mean ammonia concentration was similar in ProMix (10.1 ppm) than in Miracle-Gro (9.2 ppm). Ammonia concentration increased with increasing time after incorporation of $\mathrm{BM}$ and FM, reaching maximum values (16 $\mathrm{ppm}$ ) at day 9 and then declining to $\approx 5 \mathrm{ppm}$ (Fig. 1B).

Germination. Tomato seed germination was little affected at BM and FM rates lower than $\approx 3 \mathrm{~g} \cdot \mathrm{kg}^{-1} \mathrm{~N}(4 \% \mathrm{w} / \mathrm{w}$ for BM or $\mathrm{FM})$. Seed germination declined with increasing substrate $\mathrm{N}$ concentration above $3 \mathrm{~g} \cdot \mathrm{kg}^{-1} \mathrm{~N}$; germination reached $0 \%$ at $\approx 14 \mathrm{~g} \cdot \mathrm{kg}^{-1} \mathrm{~N}$ for both BM and FM (Fig. 2). A similar decline in germination rate was observed with $\mathrm{BM}$ compared with FM. 
Substrates significantly affected tomato germination $(P=0.0001)$. Germination percentage was lowest in Miracle-Gro (32.8\%), and there was no difference in germination percentage between those of Pro-Mix (47.4\%) and Fafard (45.1\%) (data not shown). There was no significant substrate $\times$ fertilizer interaction. Microscopic observations showed necrotic radicles and dead embryos in nongerminating seeds.

$p H$ and EC. The $\mathrm{pH}$ of substrates (ProMix and Miracle-Gro) was 5.9 in the absence of $\mathrm{BM}$ or FM. Substrate $\mathrm{pH}$ increased to about $\mathrm{pH} 7$ with addition of low rates of $\mathrm{N}$ fertilizer $\left(\approx 2.7 \mathrm{~g} \cdot \mathrm{kg}^{-1} \mathrm{~N}\right)$ (Fig. 3A). Further additions of $\mathrm{N}$ fertilizer resulted in no significant changes in substrate $\mathrm{pH}$, although $\mathrm{pH}$ tended to be higher with BM compared with FM. Across substrate N concentrations, mean $\mathrm{pH}$ was higher in Pro-Mix (7.11) than in Miracle-Gro (6.84).

Mean substrate EC increased with increasing substrate $\mathrm{N}$ concentration as supplied by BM and FM; FM, however, had a stronger effect on increasing EC compared with BM (Fig. 3B). Across substrate $\mathrm{N}$ concentrations, mean EC was higher in Pro-Mix $\left(1.30 \mathrm{dS} \cdot \mathrm{m}^{-1}\right)$ than in Miracle-Gro $\left(1.13 \mathrm{dS} \cdot \mathrm{m}^{-1}\right)$.

\section{Discussion}

Ammonia toxicity was probably the cause of inhibitory effects of BM and FM on tomato seed germination, as suggested by the high ammonia levels during the first 2 weeks after incorporation of BM and FM into the substrates. Although we cannot discard possible effects of $\mathrm{pH}$ and $\mathrm{EC}$, neither $\mathrm{pH}$ or $\mathrm{EC}$ reached values that could explain the inhibited germination observed with BM and FM rates above $3 \mathrm{~g} \cdot \mathrm{kg}^{-1} \mathrm{~N}(\approx 4 \% \mathrm{w} / \mathrm{w}$ for $\mathrm{BM}$ or $\mathrm{FM})$. Symptoms of poor seed germination resembled those caused by organic or inorganic fertilizer damage. Ammonia from $\mathrm{N}$ fertilizers (organic and inorganic) negatively affect seed germination and seedling growth of cabbage (Brassica oleracea), canola (Brassica napus), chickpea (Cicer arietinum), corn (Zea mays), cotton (Gossypium sp.), cucumber (Cucumis sativus), peanut (Arachis hypogaea), soybean (Glycine max), and wheat (Triticum sp.) (Allred and Ohlrogge, 1964; Bremner and Krogmeier, 1988; Ells et al., 1991; Megie et al., 1967; Wong et al., 1983; Woodstock and Tsao, 1986). Alfalfa (Medicago sativa) residues (chopped or extract) inhibited germination and subsequent seedling growth in cucumber (Ells et al., 1991). Soybean meal applied to soil inhibited seed germination of various vegetables (Pline and Davis, 2003). Soybean meal hydrolysate inhibited radicle growth of germinating Lolium perenne seeds in a dose-dependent manner (Yang and $\mathrm{Lu}$, 2010).

To prevent phytotoxic effects in germinating seeds, plant-based fertilizers must be incubated (mixed with the substrate before sowing) for at least 2 weeks (Koller et al., 2004). In a study using substrate containing alfalfa-based amendment, tomato
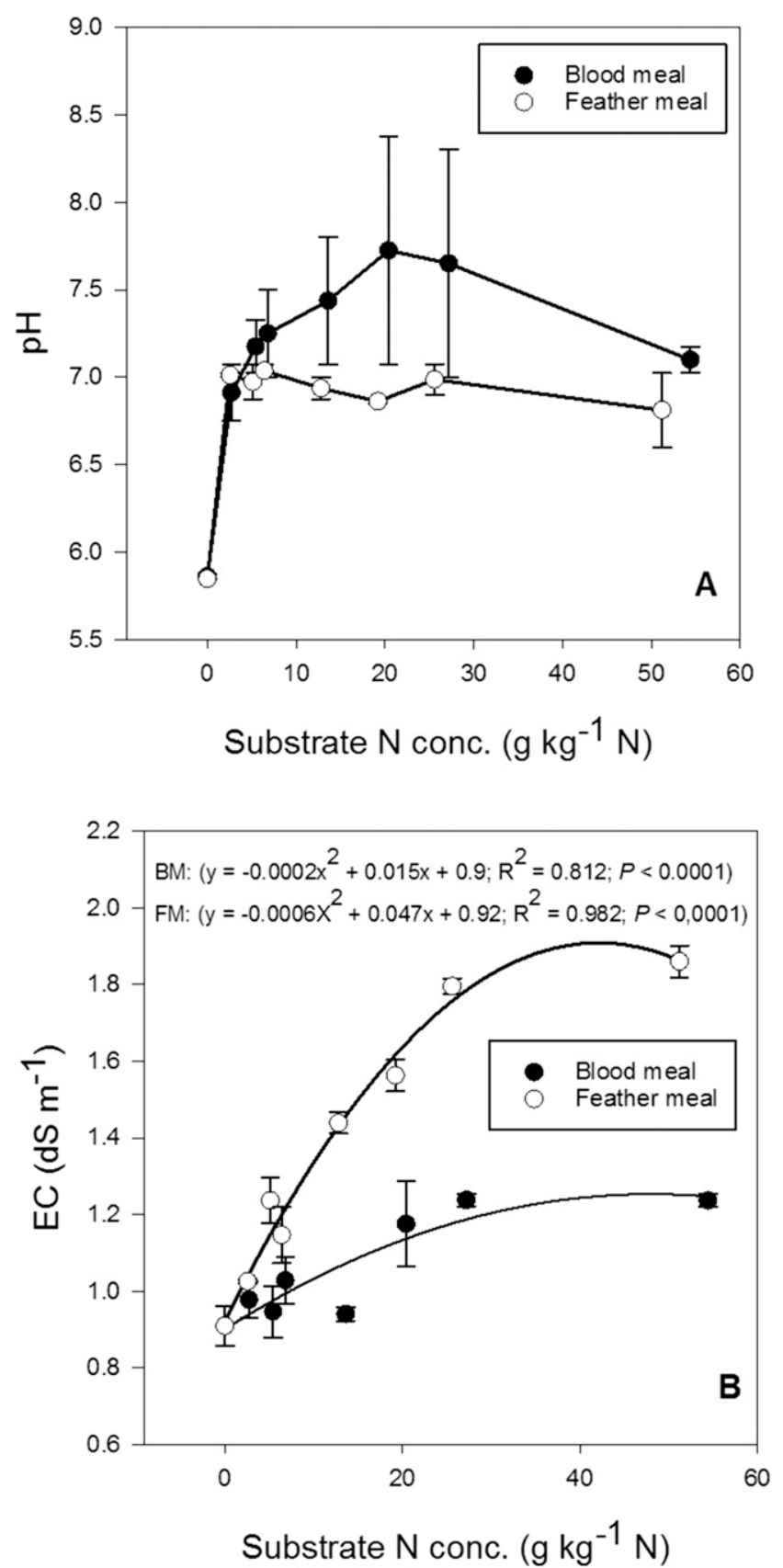

Fig. 3. Effect of nitrogen concentration in the substrate on substrate $\mathrm{pH}(\mathbf{A})$ and electrical conductivity (EC) $($ B). Nitrogen was applied as blood meal $(13.6 \% \mathrm{~N})$ or feather meal $(12.8 \% \mathrm{~N})$ organic fertilizer. Values represent means across substrates (Organic Pro-Mix and Organic Miracle-Gro). Bars indicate SE.

seed germination was less than $50 \%$ in not incubated substrate compared with a germination of $75 \%$ or greater in incubated substrate (Nair et al., 2011). Our results showed reduced ammonia levels 2 weeks after BM and FM incorporation into the substrate.

Reduced seed germination may also be caused by limited aeration caused by poor physical properties of the substrate or by cell tray geometry (Haung and NeSmith, 1999). Incorporation of BM and FM, particularly at high concentrations, may result in reduced substrate drainage and consequent low oxygen availability to germinating seeds
(Eklind et al., 2001; Hashemimajd et al., 2004). The impact of poor aeration in amended substrates, however, was not evaluated in this study.

In conclusion, BM and FM had inhibitory effects on tomato seed germination when applied at more than $3 \mathrm{~g} \cdot \mathrm{kg}^{-1} \mathrm{~N}(4 \% \mathrm{w} / \mathrm{w}$ for BM or FM). High ammonia concentration in the substrates for the first 2 weeks after incorporation of BM or FM may partially explain the inhibition of tomato seed germination. Thus, substrates amended with $\mathrm{BM}$ or FM should be allowed to incubate for at least 2 weeks before planting tomato seed. 


\section{Literature Cited}

Agehara, S. and D.D. Warncke. 2005. Soil moisture and temperature effects on nitrogen release from organic nitrogen sources. Soil Sci. Soc. Amer. J. 69:1844-1855.

Allred, S.E. and A.H. Ohlrogge. 1964. Principles of nutrient uptake from fertilizer bands. VI. Germination and emergence of corn as affected by ammonia and ammonium phosphate. Agron. J. 56:303-313.

Bremner, J.M. and M.J. Krogmeier. 1988. Elimination of the adverse effects of urea fertilizer on seed germination, seedling growth, and early plant growth in soil. Proc. Natl. Acad. Sci. USA 85:4601-4604.

Britto, D.T. and H.J. Kronzucker. 2002. NH4 toxicity in higher plants: A critical review. J. Plant Physiol. 159:567-584.

Cook, I.J. 1962. Toxic effects of urea in plants: Damage to plant roots caused by urea and anhydrous ammonia. Nature 194:1262-1263.

Díaz-Pérez, J.C., J. Silvoy, S.C. Phatak, D.S. Pitchay, and R. Morse. 2008. Organic tomato transplant production in compost-amended substrate. Acta Hort. 782:241-243.

Dufault, R.J. 1998. Vegetable transplant production. HortTechnology 8:515-523.

Eklind, Y., B. Ramert, and M. Wivstad. 2001. Evaluation of growing media containing farmyard manure compost, household waste compost or chicken manure for the propagation of lettuce (Lactuca sativa L.) transplants. Biol. Agr. Hort. 19:157-181.

Ells, J.E., A.E. McSay, and S.M. Workman. 1991. Toxic effects of manure, alfalfa, and ammonia on emergence and growth of cucumber seedlings. HortScience 26:380-383.

Gagnon, B. and S. Berrouard. 1994. Effects of several organic fertilizers on growth of greenhouse tomato transplants. Can. J. Plant Sci. 74:167168.

Hadas, A. and L. Kautsky. 1994. Feather meal, a semi-slow-release nitrogen fertilizer for organic farming. Fert. Res. 38:165-170.

Hartz, T.K. and P.R. Johnstone. 2006. Nitrogen availability from high-nitrogen-containing organic fertilizers. HortTechnology 16:39-42.

Hashemimajd, K., M. Kalbasi, A. Goichin, and H. Shariatmadari. 2004. Comparison of vermicompost and composts as potting media for growth of tomatoes. J. Plant Nutr. 27:1107-1123.

Haung, B. and D.S. NeSmith. 1999. Soil aeration effects on root growth and activity. Acta Hort. 504:215-222.

Jenkins, K. 2009. Evaluation of bat guano, blood meal, chicken manure, and feather meal as nitrogen sources for production of organic vegetable transplants. Univ. Georgia, Athens, GA, M.S. Thesis.

Khalil, M.I., M.B. Houssain, and U. Schmidhalter. 2005. Carbon and nitrogen mineralization in different upland soils of the subtropics treated with organic materials. Soil Biol. Biochem. 37:1507-1518.

Koller, M., T. Alfödi, M. Siegrist, and F. Weibel. 2004. A comparison of plant and animal based fertiliser for the production of organic vegetable transplants. Acta Hort. 631:209-215.

Megie, C.A., R.W. Pearson, and A.E. Hiltbold. 1967. Toxicity of decomposing crop residues to cotton germination and seedling growth. Agron. J. 59:197-199.

Mondini, C., M.L. Cayuela, T. Sinicco, M.A. Sanchez-Monedero, E. Bertolone, and L. Bardi. 2008. Soil application of meat and bone meal. Short-term effects on mineralization dynamics and soil biochemical and microbiological properties. Soil Biol. Biochem. 40:462-474.
Nair, A., M. Ngouajio, and J. Biernbaum. 2011. Alfalfa-based organic amendment in peatcompost growing medium for organic tomato transplant production. HortScience 46:253259.

Ni, J.Q. and A.H. Heber. 2008. Sampling and measurement of ammonia at animal facilities. Adv. Agron. 98:201-269.

Pitchay, D.S. and J.C. Díaz-Pérez. 2008. Is it possible to produce healthy organic herbal plug seedlings through different proportions of organic materials? Acta Hort. 782:215222.

Pline, M. and J. Davis. 2003. Soybean meal: Phytotoxic potential of a material used as an organic fertilizer. HortScience 38:756.

Russo, V. 2005. Organic vegetable transplant production. HortScience 40:623-628.

Valenzuela, H.R., T. Goo, and T. Radovich. 2001. The effect of bone meal on the yield of jicama, Pachyrhizus erosus, in Oahu, Hawaii. Proc. Annu. Meet. Fla. State Hort. Soc. 113:222-226.

Wong, M.H., Y.H. Cheung, and C.L. Cheung. 1983. The effects of ammonia and ethylene oxide in animal manure and sewage sludge on the seed germination and root elongation of Brassica parachinensis. Environ. Pollut. 30:109-123.

Woodstock, L.W. and H. Tsao. 1986. Influence of ammonia vapors on the dry seeds of soybeans, corn, and peanut. Crop Sci. 26:631-634.

Yang, J.A. and C.Y. Lu. 2010. Possible mechanism associated with herbicidal activity of soybean meal hydrolysate (SMH). Agr. Sci. China 9:854-860

Zak, D.R., W.E. Holmes, N.W. MacDonald, and K.S. Pregitzer. 1999. Soil temperature, matric potential, and the kinetics of microbial, respiration and nitrogen mineralization. Soil Sci. Amer. J. 63:575-584. 